\title{
Restoration of a degraded area using soil tillage systems in Campinas, São Paulo, Brazil
}

\author{
G. A. de Medeiros ${ }^{1}$, L. A. Daniel ${ }^{2}$, J. R. de F. Lucarelli ${ }^{3}$, \\ C. R. Espíndola ${ }^{2}$, A. I. Ribeiro ${ }^{1}$, F. A. G. V. Reis ${ }^{1}$ \& R. M. Longo ${ }^{4}$ \\ ${ }^{1}$ Universidade Estadual Paulista, UNESP, Brazil \\ ${ }^{2}$ Centro Estadual de Educação Tecnológica Paula Souza, Brazil \\ ${ }^{3}$ Universidade Estadual de Campinas, UNICAMP, Brazil \\ ${ }^{4}$ Pontificia Universidade Católica de Campinas, PUCCAMP, Brazil
}

\begin{abstract}
In Brazil the intensive agriculture use, mainly pasture, is the main cause of the presence of extensive areas of degraded lands. This study aimed to assess the impact of different soil management practices in a pasture degraded area used as garbage disposal. The experiment was performed at the Faculdade de Engenharia Agrícola, Universidade Estadual de Campinas - UNICAMP, in Campinas, state of São Paulo, Brazil, from 1990 to 1996. This area has undergone a process of recovery through removal of trash deposited on the surface, in 1985, levelling of soil, followed by application of limestone, subsoiling, planting of legumes (Crotalaria juncea) and crop rotation (soybean and maize). Since 1990 only popcorn maize was grown and established plots managed with different soil tillage systems, including harrow, chisel plow, moldboard plow, no tillage, disk plow and revolving hoe. One plot was planted exclusively with guinea grass (Panicum maximum) to serve as a reference for minimum loss of soil and another grown on a downhill direction to correspond to the expected maximum erosion. There were differences in sediment loss, nutrient loss and productivity of the popcorn maize in the period analyzed. The chisel plow and no tillage treatments caused the slightest loss of soil and nutrients, compared to other tillage systems. The results show that the soil management systems influenced the physical and chemical characteristics of soil, allowing an economical and environmental recovery of the area, providing the conditions for grain agricultural production. Keywords: land degradation, soil restoration, erosion, environmental impact.
\end{abstract}




\section{Introduction}

In Brazil, the pasture area is estimated at 178 million hectares where cultivated (100 million hectares) prevail on rangeland (78 million hectares) (Spavorek et al.

[1]). This area supports a growing production of meat that led to an increase of the cattle herd from 147 million heads in 1997 to 219 million heads in 2010 (IBGE [2]). However, several authors have pointed to a degradation of Brazilian pastures, with estimates ranging from 20 to 40 million hectares (Batistella et al. [3], Peron and Evangellista [4]).

Different factors have been pointed out for the degradation of pasture areas in various regions of Brazil and other countries, such as lack of replenishment of nutrients, soil acidification, loss of organic matter, soil compaction, droughts, overexploitation of pasture by animals, climate change etc., leading to the emergence of pests, weeds and erosion (Peron and Evangelista [4], Li et al. [5])

The introduction of legumes and grasses and agricultural production including the management of soil and plant have been identified by authors from different countries as an alternative to the reclamation of degraded pasture ( $\mathrm{Li}$ et al. [5], Alcantara et al. [6], Moreira et al. [7], Papanastasis [8]) and those subject to other types of degradation, such as mining activities (Chaer et al. [9], Favaretto et al. [10], Longo et al. [11]) and civil construction (Chaer et al. [9], Alves and Souza [12]). However, few studies address the recovery of areas that were used for the disposal of garbage, without any care for the environment, although this practice is still quite widespread in Brazil (Medeiros et al. [13]).

The main goal of this research was to evaluate the recovery of a degraded pasture area, which served for waste disposal, through the introduction of tillage and crop production in sub-tropical environmental conditions.

\section{History of the experimental area and implementation of conservation experiment}

The field experiments were carried out at the Faculdade de Engenharia Agrícola (FEAGRI) of Universidade Estadual de Campinas (UNICAMP), municipality of Campinas, state of São Paulo, Brazil, at latitude $22^{\circ} 49^{\prime} 16^{\prime}$ 'S, longitude $47^{\circ} 03^{\prime} 44^{\prime \prime} \mathrm{W}$ and $606 \mathrm{~m}$ above mean sea level (Figure 1). The soil is an oxisoil, classified as red Latossol by the Brazilian System of Soil Classification (Embrapa [14]). It is a clayey (61\% clay) and well-drained soil. In this area, in 1985 , there was a degraded pasture with waste glass and metals, which indicates its use in the past as a possible landfill buried (Daniel [15]).

In 1985 it was begun the building of an experimental module for measurements of soil and water loss (Daniel [15]). Each experimental plot had an area of $600 \mathrm{~m}^{2}$ and a collector of $20 \mathrm{~m}$ wide by $30 \mathrm{~m}$ long ramp (Figure 2), with a $9 \%$ slope, exposure west and north-south orientation. This year, the ground was levelled and waste disposed was withdrawn from the surface, leaving only fragments buried near the surface. 


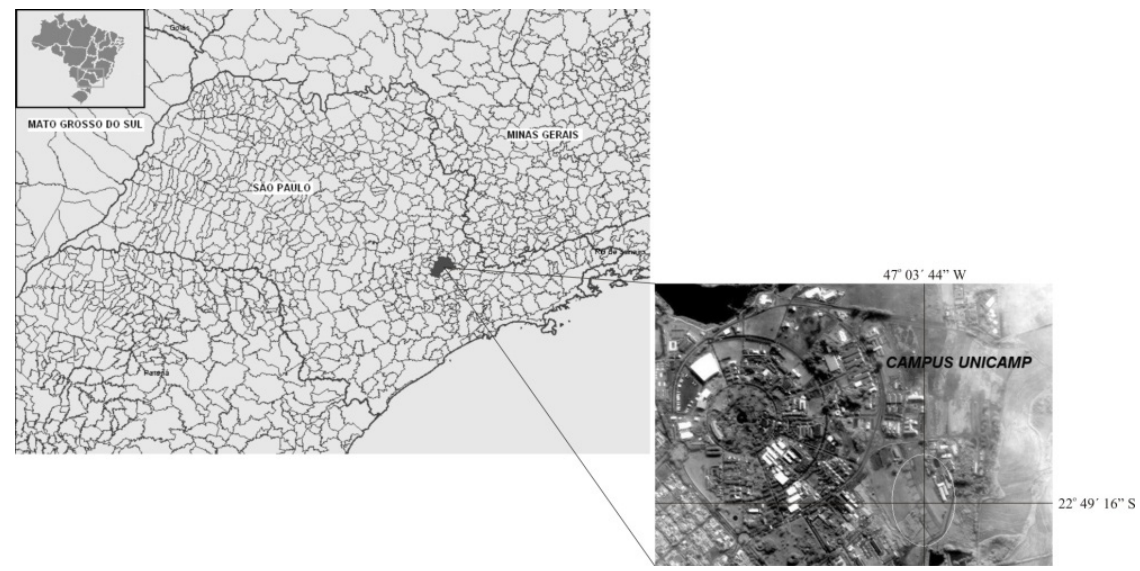

Figure 1: Location of research area at FEAGRI/UNICAMP, city of Campinas, Brazil (Medeiros et al. [16]).

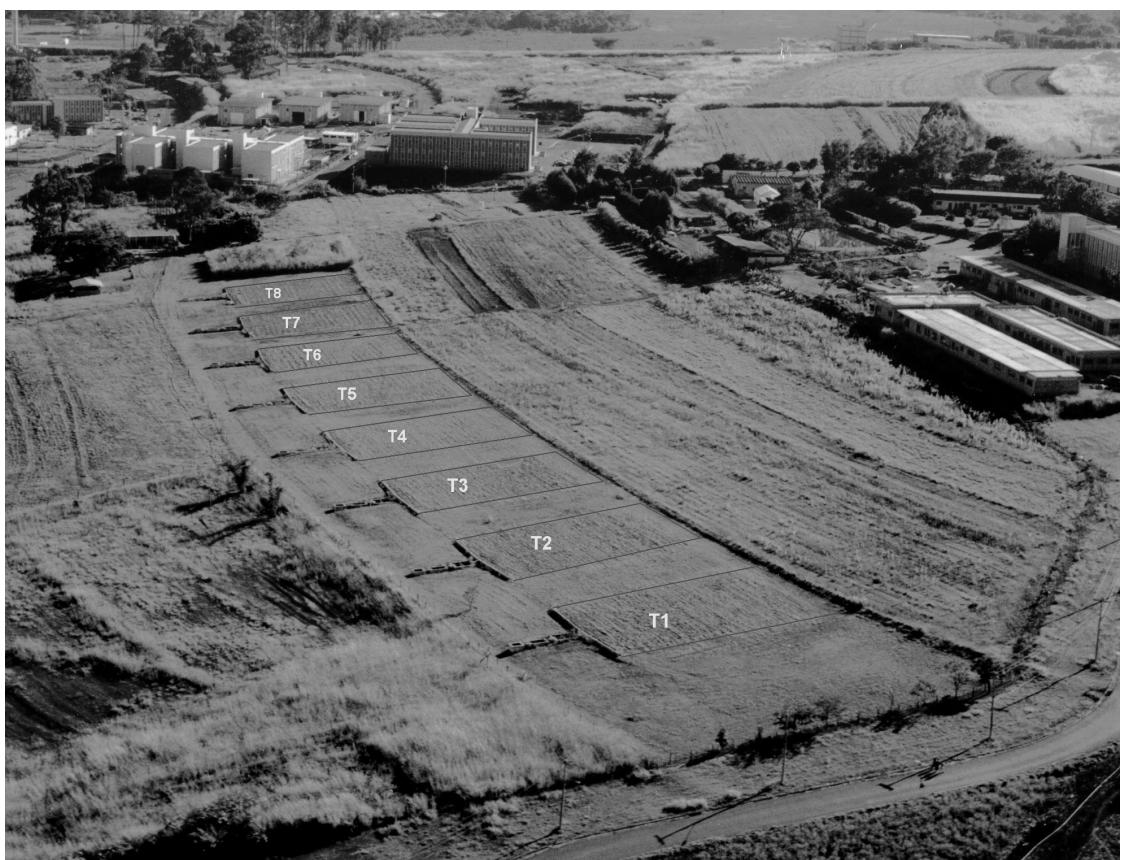

Figure 2: Aerial view of the experimental plots: conventional system with harrow disc (T1); alternate equipment (T2); chisel ploughing system (T3); no tillage (T4); disk ploughing system (T5); rangeland (T6); conventional system with disc plough worked on a downhill direction (T7); revolving hoe system (T8). 
During the agricultural year 1986/1987 (from July 1986 to June 1987) all plots were subsoiled and planted with sunhep (Crotalaria-júncea L.) to uniform the experimental area. In the following crop year (1987/1988), maize was grown in the whole area, preceded by new subsoiling. In the subsequent agricultural year (1988/1989), soybean was cropped throughout the area, to practice crop rotation, again applying the subsoiling. From June 1989 to July 1990 corn crop was grown in the whole area, with new subsoiling. In the period from June 1990 to July 1991 they were conducted different agricultural mechanization treatments in each plot collector, leaving the natural vegetation as cover, as following:

Conventional system with harrow disc (T1): carried out two heavy offset disc harrowing to $0.20 \mathrm{~m}$ deep followed by a light disc harrowing, at the time of sowing;

Alternate system equipment (T2): alternates every year the tillage implement used, repeating it every four years. The following sequence is used: tillage with harrow in the first year, followed by disk plow, moldboard plow and chisel plow in the other years.

Chisel ploughing system (T3): carried out a chisel ploughing to $0.30 \mathrm{~m}$ depth, followed by a light disc harrowing;

No tillage (T4): herbicide was applied before planting and carried out a mowing ten days after sowing. The planting was carried out with sowingfertilizer for no-tillage system, without prior mobilization of soil;

Disk ploughing system (T5): three reversible disk plough 26" incorporated crop residues to $0.20 \mathrm{~m}$ deep. At the time of sowing, it was carried out a second ploughing at $0.25 \mathrm{~m}$ depth, followed by a light disk harrowing;

Rangeland (T6): plot area used as a witness without any soil tillage, which predominates guinea grass (Panicum maximum Jac.). It was controlled by only one mowing a year and then left fallow;

Conventional system with disk ploughing on a downhill direction (T7): This plot corresponded to the expected maximum erosion. The disk ploughing tillage system was carried out, in the direction of slope;

Revolving hoe system (T8): Single soil tillage was carried out with a revolving hoe to $0.18 \mathrm{~m}$ deep, to incorporate crop residues.

\section{Material and methods}

\subsection{Soil physical-hydric parameters}

The survey of soil physical-hydric parameters was performed in 1996 in the trenches, located in the center of each experimental plot. This survey includes the bulk density and infiltration rate by means of the double-ring infiltrometer, as described by Boers et al. [17].

\subsection{Eroded soil}

The soil lost from each plot was stored in collecting boxes in the period from 1990 to 1996 . After completing the agricultural year, which corresponded to the 
period of a year from July to June of the following year, the soil was weighed and its fertility analyzed. The chemical parameters of soil lost, collected annually, corresponded to organic matter (OM), the concentration of phosphorus $(\mathrm{P})$, potassium $(\mathrm{K})$, calcium $(\mathrm{Ca})$ and magnesium $(\mathrm{Mg})$.

\subsection{Productivity}

The popcorn maize crop was cultivated once a year, from November to February the following year during the rainy season. Crop productivity was determined from the dry weight of the grains and the planted area.

\section{Results}

Table 1 shows the bulk density results by soil horizon to the different soil tillage systems, in 1996.

Table 1: Bulk density of soil horizons in experimental plots of soil tillage systems, in Campinas - SP, in 1996.

\begin{tabular}{|c|c|c|c|c|c|}
\hline $\begin{array}{c}\text { Soil } \\
\text { Horizon }\end{array}$ & Depth & Density & $\begin{array}{c}\text { Soil } \\
\text { Horizon }\end{array}$ & Depth & Density \\
\hline & $\mathrm{cm}$ & $\mathrm{Mg} \mathrm{dm}^{-3}$ & & $\mathrm{~cm}$ & $\mathrm{Mg} \mathrm{dm}^{-3}$ \\
\hline \multicolumn{3}{|c|}{ Conventional system with harrow disc } & \multicolumn{3}{|c|}{ Alternate System Equipment } \\
\hline Ap & $0-15$ & 1.13 & Ap & $0-21$ & 1.18 \\
\hline Ap2 & $15-30$ & 1.52 & Ap2 & ----- & ----- \\
\hline $\mathrm{AB}$ & $30-40$ & 1.34 & $\mathrm{AB}$ & $21-41$ & 1.52 \\
\hline $\mathrm{BA}$ & $40-59$ & 1.28 & BA & $41-65$ & 1.33 \\
\hline Bw1 & 59-92 & 1.17 & Bw1 & $65-85$ & 1.20 \\
\hline \multicolumn{3}{|c|}{ Chisel ploughing system } & \multicolumn{3}{|c|}{ No tillage } \\
\hline Ap & $0-26$ & 1.17 & Ap & $0-13$ & 1.20 \\
\hline Ap2 & ---- & ----- & Ap2 & $13-28$ & 1.43 \\
\hline $\mathrm{AB}$ & $26-51$ & 1.28 & $\mathrm{AB}$ & $28-46$ & 1.30 \\
\hline $\mathrm{BA}$ & $51-79$ & 1.21 & BA & $46-74$ & 1.25 \\
\hline Bw1 & 79-95 & 1.17 & Bw1 & $74-110$ & 1.17 \\
\hline \multicolumn{3}{|c|}{ Disk ploughing system } & \multicolumn{3}{|c|}{ Rangeland } \\
\hline Ap & $0-10$ & 1.25 & Ap & $0-13$ & 1.30 \\
\hline Ap2 & $10-18$ & 1.35 & Ap2 & ---- & ----- \\
\hline $\mathrm{AB}$ & $18-49$ & 1.18 & $\mathrm{AB}$ & $13-40$ & 1.34 \\
\hline BA & $49-70$ & 1.19 & BA & $40-61$ & 1.27 \\
\hline Bw1 & $70-96$ & 1.10 & Bw1 & $61-99$ & 1.14 \\
\hline \multicolumn{3}{|c|}{ Disk ploughing on downhill direction } & \multicolumn{3}{|c|}{ Revolving hoe system } \\
\hline Ap & $0-16$ & 1.27 & Ap & $0-18$ & 1.06 \\
\hline Ap2 & ---- & ---- & Ap2 & ----- & ----- \\
\hline $\mathrm{AB}$ & $16-42$ & 1.23 & $\mathrm{AB}$ & $18-48$ & 1.29 \\
\hline BA & $42-68$ & 1.16 & BA & $48-68$ & 1.13 \\
\hline Bw1 & $68-105$ & 1.12 & Bw1 & $68-105$ & 1.10 \\
\hline
\end{tabular}


Considering all soil horizons, conventional system with harrow disc, alternate system equipment and no-tillage showed higher values, while the treatments disk ploughing system, disk ploughing on a downhill direction and revolving hoe system presented the lower bulk density results, according to Table 1 . The lower bulk density is associated with increased soil disturbance.

No-tillage showed a bulk density close to the rangeland, which receives only the traffic of agricultural machinery used in agricultural operations of the other plots.

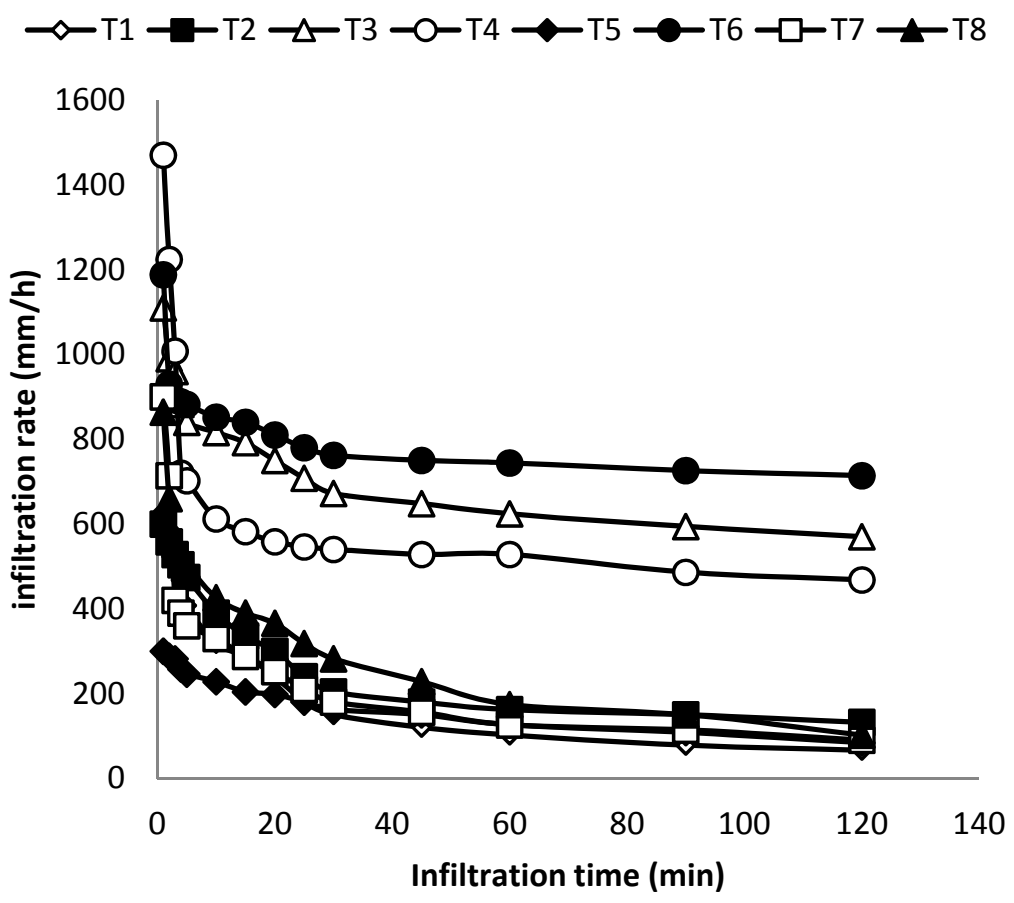

Figure 3: Infiltration rate to different soil tillage systems, in Campinas, state of São Paulo, Brazil, in 1996.

Despite the relatively higher values of bulk density when compared to other soil tillage systems, these treatments provided along with the chisel ploughing system, the higher observed infiltration rates (Figure 4). One of the reasons for this phenomenon is the greater biological activity in no-till and rangeland experimental plots, leading to pore formation in the soil by the action of dead roots, earthworms, termites and ants, as reported by Lucarelli [18].

The infiltration rate ranged from $66 \mathrm{~mm} \mathrm{~h}^{-1}$ (conventional system with harrow disc) to $714 \mathrm{~mm} \mathrm{~h}^{-1}$ (rangeland). The lower infiltration rates were observed in the treatments that increased soil disturbance as harrow disc, disk ploughing system, disk ploughing on a downhill direction and revolving hoe system which reached 
$66 \mathrm{~mm} \mathrm{~h}^{-1}, 84 \mathrm{~mm} \mathrm{~h}^{-1}, 90 \mathrm{~mm} \mathrm{~h}^{-1}$ and $102 \mathrm{~mm} \mathrm{~h}^{-1}$. Alternate system equipment, no tillage and chisel ploughing had infiltration rates of $132 \mathrm{~mm} \mathrm{~h}^{-1}, 468 \mathrm{~mm} \mathrm{~h}^{-1}$ and $570 \mathrm{~mm} \mathrm{~h}^{-1}$ respectively.

The soil and nutrient losses in the experimental plots are presented in Table 2. It was observed the lowest loss of sediment in the rangeland and the largest in disk ploughing on a downhill direction treatment, reaching an average of $73.2 \mathrm{~kg}$ $\mathrm{ha}^{-1}$ harvest $^{-1}$ and 4,677.8 $\mathrm{kg} \mathrm{ha}^{-1}$ harvest $^{-1}$ respectively, in the period from 1990 to 1996.

Table 2: Average productivity of popcorn, soil and nutrient loss from experimental plots of soil tillage systems, in Campinas, state of São Paulo, Brazil, from 1990 to 1996.

\begin{tabular}{|c|c|c|c|c|c|c|c|}
\hline \multirow[t]{2}{*}{ Treat } & \multirow[t]{2}{*}{ Productiv } & \multirow[t]{2}{*}{ Soil Loss } & \multicolumn{5}{|c|}{ Nutrient loss } \\
\hline & & & $\mathrm{OM}$ & $\mathrm{P}$ & $\mathrm{K}$ & $\mathrm{Ca}$ & $\mathrm{Mg}$ \\
\hline & \multicolumn{7}{|c|}{ 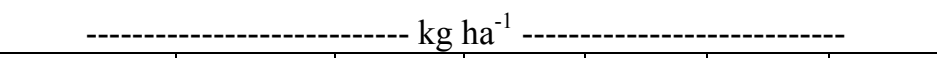 } \\
\hline $\mathrm{T} 1$ & 2,167 & 623.4 & 31.28 & 0.056 & 0.100 & 1.82 & 0.43 \\
\hline $\mathrm{T} 2$ & 1,918 & 585.3 & 25.36 & 0.048 & 0.087 & 1.48 & 0.36 \\
\hline T3 & 1,543 & 525.6 & 25.85 & 0.037 & 0.086 & 1.41 & 0.27 \\
\hline $\mathrm{T} 4$ & 1,725 & 121.3 & 7.79 & 0.012 & 0.021 & 0.59 & 0.18 \\
\hline T5 & 1,690 & 606.8 & 27.71 & 0.037 & 0.067 & 2.22 & 0.58 \\
\hline T6 & ------ & 73.2 & 5.16 & 0.053 & 0.011 & 0.38 & 0.17 \\
\hline $\mathrm{T} 7$ & 1,586 & $4,677.8$ & 164.51 & 0.059 & 0.278 & 4.48 & 1.13 \\
\hline $\mathrm{T} 8$ & 1,400 & $1,475.8$ & 75.27 & 0.025 & 0.091 & 1.99 & 0.35 \\
\hline
\end{tabular}

Treat: treatment; productive: average productivity

Considering the tillage systems and soil management evaluated, the highlight was the no tillage, where soil loss reached $121.3 \mathrm{~kg} \mathrm{ha}^{-1}$ harvest $^{-1}$. Treatments T1, T5, T3, and T2 had comparable losses of soil and reached $623.4 \mathrm{~kg} \mathrm{ha}^{-1}$ harvest $^{-1}, 606.8 \mathrm{~kg} \mathrm{ha}^{-1}$ harvest $^{-1}, 585.3 \mathrm{~kg} \mathrm{ha}^{-1}$ harvest $^{-1}$ and $525.6 \mathrm{~kg} \mathrm{ha}{ }^{-1}$ harvest $^{-1}$ respectively.

In the revolving hoe experimental plot it was observed the highest soil losses among tillage systems evaluated, reaching $1,475.8 \mathrm{~kg} \mathrm{ha}^{-1}$ harvest $^{-1}$, during the period studied.

The treatments that mobilized the ground in excess, leaving little coverage, also caused relatively large nutrient loss, especially organic material, such as conventional system with harrow disc, which showed the poorest performance, presenting higher loss of organic matter and nutrients (Table 2). This negative result in relation to conservation systems can be explained by the high degree of mobilization, disruption and formation of compacted subsurface layers that promote such systems, which provided high losses of land and water, and consequently organic matter and nutrients. 
The average productivity of popcorn maize crop (Zea mays L.) to soil and climate conditions in the state of Sao Paulo, cultivated in the rainy season, to the varieties used during the experimental period reach $1,500 \mathrm{~kg} \mathrm{ha}^{-1}$ harvest $^{-1}$ (Sawazaki and Miranda [19]), which is lower than that observed in varieties developed later in Brazil (Sawazaki et al. [20], Carpentieri-Pípolo et al. [21], Rangel et al. [22])

Average productivity in the period of the field experiment ranged from 1400 to $2,167 \mathrm{~kg} \mathrm{ha}^{-1}$ harvest $^{-1}$. The tillage system that showed the worst average productivity was the revolving hoe, which reached $1,400 \mathrm{~kg} \mathrm{ha}^{-1}$ harvest ${ }^{-1}$, while the best performance was the conventional system with harrow disc, which average productivity reached $2,167 \mathrm{~kg} \mathrm{ha}^{-1}$ harvest $^{-1}$. With exception of the revolving hoe, the other tillage systems and soil management reached and exceeded the average productivity for popcorn crop, demonstrating its effectiveness in the recovery of degraded areas evaluated in this study.

\section{Conclusion}

The present work has demonstrated the effectiveness of tillage systems and soil management, especially those classified as conservationists, to the recovery of degraded rangeland with a history of use for the disposal of domestic solid wastes.

The popcorn maize productivity for the cultivation conditions and variety of seed used, reached levels comparable to those observed average productivity in the state of São Paulo, except for the revolving hoe system. This characteristic, combined with reduced loss of soil and nutrients, make no tillage the technique more aligned with the principles of sustainable agriculture within the tropical environment of this work, with regard to economic and environmental aspects.

\section{References}

[1] Sparovek, G., Correchel, V. and Barreto, A.G.O.P. The risk of erosion in Brazilian cultivated pastures. Scientia Agricola, 64(1), pp. 77-82, 2007.

[2] IBGE (Instituto Brasileiro de Geografia e Estatística). Statistics on livestock. Available on http:/www.ibge.gov.br/home/download/ estatistica.shtm Access on March 6, 2012.

[3] Batistella, M., Andrade, R.G., Bolfe, E.L. et al. Geotechnologies and territorial management of Brazilian cattle. Revista Brasileira de Zootecnia, 40(SE), pp. 251-260, 2011. (in Portuguese)

[4] Peron, A.J. and Evangelista, A.R. Pasture degradation in savanna's regions. Ciência e Agrotecnologia, 28(3), pp. 655-661, 2004. (in Portuguese)

[5] Li, X.L., Gao, J., Brierley, G., Qiao, Y.M., Zhang, J. and Yang, Y.W. Rangeland degradation on the Qinghai-Tibet Plateau: implications for rehabilitation. Land Degradation \& Development, 9 pp., 2011.

[6] Alcantara, F.A., Furtini Neto, A.E., Paula, M.B., Mesquita, H.A. and Muniz, J.A. Green manuring in the recovery of degraded oxisoil fertility. 
Pesquisa Agropecuária Brasileira, 35(2), pp. 277-288, 2000. (in Portuguese)

[7] Moreira, J.A.A., Oliveira, I.P., Guimarães, C.M. and Stone, L.F. Chemical and physical attributes of a dystrophic oxisol under reclaimed and degraded pastures. Pesquisa Agropecuária Tropical, 35(3), pp. 155-161, 2005. (in Portuguese)

[8] Papanastasis, V.P. Restoration of Degraded Grazing Lands through Grazing Management: Can It Work? Restoration Ecology, 17(4), pp. 441-445, 2009.

[9] Chaer, G.M., Resende, A.S., Campello, E.F.C., Faria, S.M. and Boddey, R.M. Nitrogen-fixing legume tree species for the reclamation of severely degraded lands in Brazil. Tree Physiology, 31, pp. 139-149, 2011.

[10] Favaretto, N., Moraes, A., Motta, A.C.V. and Prevedello, B.M.S. Effect of revegetation and of fertilization of degraded area on production of dry matter and on nutrient uptake. Pesquisa Agropecuária Brasileira, 35(2), pp. 299-306, 2000. (in Portuguese)

[11] Longo, R.M., Ribeiro, A.I. and Melo, W.J. Use of green fertilizing in the recovery of soils degraded by mining in the Amazon forest. Bragantia, 70(1), pp. 139-146, 2011. (in Portuguese)

[12] Alves, M.C. and Souza, Z.M. Soil reclamation by green manure and soil amendments in areas degraded by hydroelectric power plant construction. Revista Brasileira de Ciência do Solo, 32, pp. 2505-2516. (in Portuguese)

[13] Medeiros, G.A., Reis, F.A.G.V., Menezes, P.H.B.J. et al. Diagnosis at the dump area of Poços de Caldas, state of Minas Gerais, Brazil. Engenharia Ambiental, 6(2), pp. 03-15, 2009. (in Portuguese)

[14] Embrapa (Empresa Brasileira de Pesquisa Agropecuária) Sistema brasileiro de classificação de solos. Ministério da Agricultura e do Abastecimento: Rio de Janeiro, Brazil, 412 p., 1999. (in Portuguese)

[15] Daniel, L.A. O Campo experimental da FEAGRI. A Engenharia Agrícola na UNICAMP, org. W.J. Freire, FEAGRI/Sitta Gráfica e Editora: Campinas, pp. 64-64, 2005.

[16] Medeiros, G.A., Daniel, L.A., Lucarelli, J.R.F. and Reis, F.A.G.V. Influence of the soil tillage and management in a Latossolo vermelho on its physical and hydrics properties. Geociências, 28(4), p. 453-465, 2009. (in Portuguese)

[17] Boers, Th.M., van Deurzen, F.J.M.P., Eppink, L.A.A.J. and Ruytenberg, S.E. Comparison of infiltration rates measured with an infiltrometer, a rainulator and a permeameter for erosion research in SE Nigeria. Soil Technology, 5, pp. 13-26, 1992.

[18] Lucarelli, J.R.F. Alterações em características de um Latossolo roxo submetido a diferentes sistemas de manejo. UNICAMP: Campinas, Brazil, 1997.

[19] Sawazaki, H.E. and Miranda, M.A.C. Instruções agrícolas para o Estado de São Paulo. Instituto Agronômico: Campinas, Brazil, 1990.

[20] Sawazaki, E., Paterniani, M.E.A.G.Z., Castro, J.L., Galo, P.B., Galvão, J.C.C. and Saes, L.A. Inbred line potentials for the synthesis of new popcorn hybrids. Bragantia, 59(2), p.143-151, 2000. (in Portuguese) 
[21] Carpentieri-Pípolo, V., Takahashi, H.W., Endo, R.M., Petek, M.R. and Seifert, A.L. Correlações entre caracteres quantitativos em milho pipoca. Horticultura Brasileira, 20(4), p.551-554, 2002. (in Portuguese)

[22] Rangel, R.M., Amaral Júnior, A.T., Gonçalves, L.S.A., Freitas Júnior, S.P. and Candido, L.S. Biometric analysis of selection gains in popcorn population of the fifth cycle of recurrent selection. Revista Ciência Agronômica, 42(2), p.473-481, 2011. 